\title{
Які тренди нейрофармакології варті нашої уваги?
}

\author{
Г.В. Зайченко \\ Національний медичний університет імені О.О. Богомольця, Київ, Україна
}

Сучасний світ ліків дуже різноманітний, і лікарям досить складно орієнтуватися в ньому. Сьогодні на фармацевтичному ринку наявні як препарати природного, так і синтетичного походження. При цьому є препарати-проліки, які перетворюються на ліки в організмі, і препарати, які, потрапляючи в організм, одразу починають діяти. Ліки можуть бути оригінальними - інноваційними, що захищені патентами, і генеричними. I якщо оригінальний препарат характеризується передбачуваністю, добре вивченими аспектами фармакокінетики і фармакодинаміки, то генеричний ще повинен «довести» свою ідентичність оригінатору, пройшовши всі етапи дослідження еквівалентності. Особливістю вітчизняного фармацевтичного ринку є те, що ліки можна придбати без рецепта лікаря, на відміну від розвинених країн, де дуже жорстко обмежена промоція препаратів і без рецепта лікаря відпускають лише засоби симптоматичної дії, а практично всі лікарські препарати неврологічної групи - виключно рецептурні. Натепер з'явилися «орфанні», рідкісні та високовартісні ліки, що призначені для лікування «захворювань-сиріт», і навпаки «блокбастери», що стрімко завоювали фармацевтичний ринок і стали лідерами продажу. $\epsilon$ традиційні препарати, які знаходяться на ринку багато років і добре відомі, і $\epsilon$ інноваційні, які тільки-но з'явилися і про які ми знаємо значно менше (біотехнологічні препарати, моноклональні антитіла, фьюжн-білки, нанопрепарати, їх біосиміляри), і повинно минути як мінімум 20 років, щоб людство добре вивчило їх дію і навчилося максимально ефективно і безпечно їх використовувати. Існують алопатичні (їх ефекти протилежні симптомам хвороби: наявний біль - зменшують його вираженість, підвищена температура тіла - знижують її и т.д.) і гомеопатичні препарати (які діють за принципом «подібне лікує подібне»). Знати і пам'ятати все це - важливі компетенції сучасного лікаря, які необхідно постійно вдосконалювати і відточувати. Лікар повинен бути «в тренді» фармацевтичних інновацій, а місія фармаколога - допомогти лікарю розібратися у складних аспектах фармакодинаміки нових і традиційних ліків, щоб він мав можливість приймати виважені і обґрунтовані рішення під час фармакотерапії.

Сьогодні відбувається «ренесанс» ліків природного, зокрема рослинного, походження. Лікарські препарати, які отримано з рослин, дуже активно удосконалюються і впроваджуються в ті чи інші сфери медицини. Цьому сприяють значна потреба в таких препаратах та їх популярність серед населення. Дуже важливим моментом $\epsilon$ те, що на сучасному етапі добре вивчені і продовжують вивчатися молекулярні механізми дії цих ліків, розшифровуються їх будова, структура, склад, уточнюється, які частини екстрактів «діють», а які, навпаки, - заважають. Очистка, стандартизація, дозування - все це приводить до того, що сучасні фітопрепарати дуже відрізняються за своїми лікувальними і фармацевтичними властивостями від «стареньких» лікарських препаратів, отриманих із рослин. Ті інноваційні технології, які прийшли сьогодні у фармацевтику, відкривають нам зовсім інший світ ліків.

Фітопрепарати дуже змінилися буквально за останні декілька десятків років. Найпримітивніші ліки (які, до речі, сьогодні ще можна купити в аптеці) являють собою рослинну сировину: чи то листя, коріння, чи кору, з якої вдома можна самостійно зробити відвар чи настій). Відомо, що у рослині накопичуються різні хімічні структури - і ліпофільні, і гідрофільні; і вилучити їх можна за допомогою чи то води, чи спирту, чи більш серйозних технологій. Звичайно, коли рослинну сировину екстрагують примітивно, наприклад парою, - речовини, що відповідає за лікувальну дію, потрапляє «minimum minimorum». Людство зробило крок уперед, коли було отримано більш досконалі фітопрепарати: настойки, складні настойки, бальзами, що декілька разів піддавалися процесу екстракції різними екстрагентами (спиртовими, ефірними та ін.). Потім навчилися вдосконалювати рослинні препарати й отримувати сухі екстракти у формі таблеток чи капсул. Потім з'явилися суперсучасні технології, і з ліків почали вилучати тільки те, що треба, і в більшій кількості, спеціально забирати з екстракту і концентрувати лише речовини, що відповідають за фармакологічні ефекти, забирати все те, що може бути токсичним та недієвим, тобто неефективним. Все це дозволило «оптимізувати» склад фітопрепарату (зайве пішло - залишилося тільки потрібне) i, найголовніше, - очищувати, стандартизувати й чітко дозувати їх, тобто чітко розуміти, яка кількість діючої речовини потрапляє в організм.

Щоб сучасні технології та сучасні фітопрепарати працювали - треба, щоб працювала система контролю якості у фармації. Потрібний контроль виробництва будь-якого лікарського препарату, щоб на нього можна було покластися і він виправдав наші надії. У випадку з лікарськими препаратами, отриманими з рослин, цей комплекс заходів повинен здійснюватися від моменту інтродукції, посіву (спеціальних зерняток селекціонованої рослини, в яких максимально будуть накопичуватися діючі речовини) в спеціально доглянуту землю, яка здобрена усіма необхідними мінеральними й органічними елементами. Тільки тоді рослина візьме з землі максимальну користь і синтезує в собі ті молекули, які будуть потім лікувати. 3 виснажених, пустельних, глинистих ґрунтів, які багато років не оброблялися за науковими агротехнологіями, звичайно ж, рослина візьме мінімум, і отримати з такої рослини лікарську сировину дуже складно. Тому сьогодні у світі з'явився підхід GxP (Good X Practice) - належна практика виробництва ліків, а у випадку рослинних ліків - належна практика агротехнологій. Якщо рослина вирощена саме так (а не на подвір'ї чи вздовж шосейних доріг або навіть у дикому вигляді, коли, навпаки, в ній може накопичуватися все, що завгодно, - від тяжких металів, радіонуклідів тощо, яких потім буде дуже складно позбавитися) і забезпечені надійні умови культивування - це запорука в майбутньому якості й дієвості ліків. Потім з такою рослиною обходяться дуже дбайливо, забирають з неї біологічно активні речовини - і не просто спиртом або водою, а декількома екстрагентами - максимально повно, видаляють все зайве, концентрують, згущують, очищають; такі екстракти проходять декілька етапів очищення, фільтрації. Потім турботливі руки технологів перетворюють ці екстракти у зручну для застосування лікарську форму. Такі ліки обов'язково проходять багатоступінчастий контроль якості. У процесі виробництва — і на самому початку, і на виході з фармацевтичного підприємства - обов'язково вказані критерії якості і відповідність галузевим стандартам якості, фармакопейним вимогам тощо. Це дуже важливо, тому що від серії до серії препарат не змінюватиме своїх характеристик, і повторюватиме ті унікальні лікувальні властивості, які в нього вклали розробники.

Сучасні фітопрепарати проходять складну процедуру не тільки GMP (Good Manufacturing Practice) — належної виробничої практики, але й GCP (Good Clinical Practice) - належної клінічної практики, тобто вони вивчаються настільки серйозно і прицільно, що для цих препаратів теж сьогодні $є$ рівні доказовості, вони включені у протоколи, клінічні рекомендації, тому що мають доведену ефективність, на відміну від примітивних фітопрепаратів минулого. Сучасні препарати, отримані з рослин, мають і сучасний рівень доказовості. Саме тому такі фітопрепарати мають високу ефективність і значно кращий профіль безпеки по- 
рівняно з синтетичними препаратами, адже рослинні молекули дуже близькі до клітин тваринного походження, до клітин людини. Наші рецептори і клітинні утворення в першу чергу розпізнають схоже, природне, споріднене, і дуже добре сприймають молекули, отримані з рослин, швидше «включаються» до метаболічних процесів, i тому у таких препаратів особливі механізм і профіль безпеки. Важливо, що не одна сполука, а комплекс сполук, що входять до складу таких екстрактів, забезпечують фармакологічні властивості препарату. Іноді дуже складно розділити ці молекули і зрозуміти, що саме діє. Іноді вдається отримати окрему сполуку, яка діє не гірше, ніж комплекс сполук, який вилуча$\epsilon$ ться в момент екстрагування. Завдяки такому багатофакторному впливу ці препарати зачіпають й інші «струнки» здоров'я $\mathrm{i}$ чинять багатовекторну фармакологічну дію.

Сьогодні на прикладі препаратів, отриманих із лікарських рослин із застосуванням найсучасніших технологій, можна бачити, наскільки змінилися рослинні ліки, як можна їм довіряти і які нові грані в них можна знаходити. Так, фармацевтична компанія «Dr. Willmar Schwabe GmbH \& Co. KG» (Німеччина) розробила та запатентувала високостандартизований екстракт гінкго білоба EGb 761. В Україні оригінальний EGb 761 (виробник «Dr. Willmar Schwabe $\mathrm{GmbH} \&$ Co. KG») зареєстровано під торговими назвами Мемоплант (40 мг/табл.), Мемоплант форте (80 мг/табл.), Тебокан (120 мг/табл.). Лікарські засоби Мемоплант, Мемоплант форте та Тебокан відрізняються за дозою оригінального екстракту EGb $761^{\circledR}$ в 1 таблетці, для зручності та індивідуального підходу в лікуванні пацієнтів із різною патологією. Ексклюзивним постачальником в Україну цих препаратів $\epsilon$ компанія «Alpen Pharma Group» (Швейцарія). Наразі тільки компанії-виробнику відоме співвідношення біологічно активних речовин в оригінальному екстракті EGb 761® завдяки чому він виявився одним із найефективніших, продемонстрував в ході доклінічних і клінічних досліджень свою ефективність, безпеку і передбачуваність і продовжує дивувати новими й новими властивостями.

Розглядаючи фітохімічний склад екстракту, слід зазначити, що основні елементи, які забезпечують його дію, $\epsilon$ і в інших рослинах, але для EGb $761^{\circledR}$ характерні певні власні відмінності. Його властивості визначають насамперед молекули, які належать до терпенових лактонів, а також флавонових глікозидів, які забезпечують власне фармакодинамічні властивості. Слід зазначити, що в цьому екстракті дуже суворо регламентовано вміст сполук, і їх певне співвідношення. Технологія виробництва EGb $761^{\circledR}$ «Dr. Willmar Schwabe GmbH \& Co. KG» демонструє 7 ступенів якості, один із найвищих рівнів у світі. Вміст діючих речовин та очищення від небажаних домішок суворо контролюються, завдяки чому досягається постійна концентрація діючих речовин від партії до партії, що забезпечує комплексні клінічні ефекти, продемонстровані та доведені в численних рандомізованих дослідженнях та реальній клінічній практиці: антиоксидантний, антигіпоксичний, мембраностабілізуючий, судинні та гематореологічні ефекти, нейропротекція. Тому зазначені лікарські препарати (Мемоплант, Мемоплант форте, Тебокан), які містять оригінальний високостандартизований екстракт гінкго білоба EGb 761 ${ }^{\oplus}$, здатні забезпечувати всі задекларовані фармакодинамічні та лікувальні властивості препаратів. Таким чином, високостандартизований оригінальний екстракт гінкго білоба EGb $761^{\circledR}$, отриманий за сучасною технологією, містить суворо визначену певну кількість діючих речовин і забезпечує фармакодинамічні та лікувальні властивості лікарських препаратів (Мемоплант, Мемоплант форте, Тебокан).

При порівнянні екстрактів гінкго білоба інших різних виробників виявилося, що вони дуже відрізняються за вмістом основних діючих речовин - флавонових глікозидів, терпенових лактонів, з якими пов'язаний основний терапевтичний ефект, а вміст в них небажаних токсичних домішок - гінкголієвих кислот, які асоційовані з виникненням небажаних явищ, токсичності, алергогенності, мутагенності та інших побічних ефектів, в сотні і тисячі разів перевищує припустимі норми, зазначені в монографіях із стандартизації екстракту гінкго білоба (Європейській, ВОО3 та ін.).

Для препаратів рослинного походження не прийнято говорити «генерична версія», «генерична копія». Говорять «оригіналь- ний препарат» $\mathrm{i}$ «фітосиміляр» (тобто подібний), тому що повною мірою відтворити технологію і забезпечити унікальний склад діючих речовин та очистити від небажаних токсичних домішок дуже складно і, на жаль, відмінності між екстрактами різних виробників можуть бути дуже істотними та суттєвими.

На фармацевтичному ринку України досить багато і лікарських препаратів, і дієтичних добавок, що містять різні екстракти гінкго білоба. Питання: що містять ці продукти, ці фітосиміляри (у випадку, якщо це ліки), і вже й зовсім складно відповісти на запитання, що можуть містити дієтичні добавки, щодо яких не передбачена жодна процедура пре- і клінічного вивчення, стандартизації, а тільки $\epsilon$ висновок про відсутність тяжких металів і радіонуклідів у сировині? Сьогодні практично в усіх виробників немає доказів того, що їхня технологія і контроль якості екстракту хоча 6 наближаються до стандартів оригінального EGb $761^{\circledR}$.

В останні 20 років з'явилися результати ряду досліджень, в яких порівнювали між собою багато серій екстракту гінкго білоба. Дивно те, що цим займалися водночас і в країнах Європи, і в США, і в Японії. В опублікованих звітах дослідницькі групи представили цікаві дані. Вивчали до 27 різних екстрактів гінкго білоба для того, щоб оцінити різницю і ризики, пов'язані з різними виробниками. Проведено порівняння за різними показниками - і за ступенем чистоти, і за змістом гінкголієвих кислот, і за вмістом діючих речовин, а також дослідження біоеквівалентності, які дозволили перевірити, як змінюються властивості цих екстрактів залежно від виробника. Виявилося, що для деяких екстрактів неможливо досягти і половини тієї концентрації, яку створено в оригінальному екстракті EGb $761^{\oplus}$. Щось заважає вивільнятися, розчинятися, потрапляти у середовище там, де потенційно препарат повинен знайти свою мішень. Такий лікарський препарат навряд чи виявить прогнозований лікувальний ефект. У крові волонтерів перевірили концентрацію діючих речовин, які добре ідентифікуються в екстракті. Виявилося, що їх концентрація в сироватці крові далеко не співпадає з профілем фармакокінетики оригінального екстракту EGb $761^{\circledR}$. Це свідчить про те, що такі ліки працювати на рівні з оригінальними не будуть. Порівняльний аналіз показав, що деякі екстракти мають подібність до оригінального екстракту, але значно поступаються йому за вмістом головних складових (терпенових лактонів та флавонових глікозидів), а $\epsilon$ екстракти, які містять значно більше токсичних речовин (гінкголієвих кислот), і це може негативно впливати на профіль безпеки. На жаль, все це може потрапляти до споживача. Тож сьогодні дуже складно компаніям, які хочуть повторити, але не можуть проводити складні фармацевтичні дослідження, а також такі, що підтверджують біоеквівалентність екстракту.

Слід звернути увагу на вміст гінкголієвих кислот у різних екстрактах гінкго білоба. У монографіях зі стандартизації (Європейській, ВООЗ та ін.) мінімальна допустима кількість гінкголієвих кислот у екстракті гінкго білоба має становити не більше 5 ppm (або 0,0005\%, або 5 мкг). Позначення ppm (англ. parts per million, або лат. pro pro mille; читається «пі-пі-ем») — одиниця вимірювання концентрації та інших відносних величин, аналогічна за змістом відсотку або проміле, та являє собою одну мільйонну частку (перерахунок 1 ppm=0,001\%o=0,0001\%=0,000001=10-6). У лікарських препаратах оригінального EGb 761 ${ }^{\circledR}$ (компанії «Dr. Willmar Schwabe GmbH \& Co. KG») Мемоплант, Мемоплант форте, Тебокан вміст гінкголієвих кислот становить 0,2; 0,4 та 0,6 мкг відповідно, що у $25 ; 12,5$ та 8 разів менше ніж мінімальний допустимий рівень, зазначений у монографіях із стандартизації. Інформація про вміст гінкголієвих кислот вказана в інструкціях для медичного застосування цих препаратів. В інструкціях інших виробників лікарських препаратів гінкго білоба або БАД (дієтичних добавках), які зареєстровані в Україні, вміст гінкголієвих кислот не зазначено взагалі, або зазначено не точно (не більше 5 рpm, або 0,0005\%). При проведенні контролю якості на хроматограмі піки гінкголієвих кислот інших виробників зашкалювали. Аналіз 27 екстрактів гінкго білоба показав, що вміст гінкголієвих кислот у деяких торгових марках перевищував у 40 тис. разів мінімальне допустиме значення (вказане в монографіях із стандартизації екстракту гінкго білоба) настільки можуть відрізнятися різні екстракти! 
Дивовижні властивості оригінального високостандартизованого екстракту гінкго білоба EGb $761^{\circledR}$, що відрізняють його від інших екстрактів, забезпечують високу якість та високий профіль безпеки, на відміну від екстрактів гінкго білоба інших виробників. Наскільки це позначається на авторитеті препарату? По-перше, це - високий рівень доказовості тих досліджень, які проведені на EGb $761^{\circledR}$. Стандартизований продукт демонструє прогнозовану фармакодинаміку і ефекти: звідси велика кількість досліджень і відповідна доказова база. Найголовніше з фармакологічної точки зору - здатність проникати у головний мозок і наявність доказів того, що препарат накопичується, або фіксується, у тих відділах мозку, звідки очікуємо на фармакологічний ефект. Для оригінального EGb $761^{\oplus}$ це доведено: верифіковані відділи головного мозку, показано, де саме відбувається накопичення цього екстракту, і стає зрозуміло, за рахунок чого проявляються його унікальні властивості. Для інших екстрактів таких досліджень не проводилося. Таким чином, можливість проникати у структури головного мозку забезпечує екстракту EGb $761^{\oplus}$ його нейротропні властивості, здатність покращувати пам'ять, покращувати когнітивні функції - навчання, концентрацію уваги тощо. На сьогодні визначено мультифакторний механізм дії оригінального екстракту гінкго білоба. EGb $761^{\oplus}$ нормалізує обмін речовин у клітинах, реологічні властивості крові і мікроциркуляцію; покращує мозковий кровообіг і забезпечення мозку киснем і глюкозою; виявляє дозозалежний регулюючий вплив на судинну систему, стимулює продукування ендотелійзалежного послаблювального фактора (оксид азоту - NO), розширює дрібні артерії, підвищує тонус вен, тим самим регулює кровонаповнення судин; знижує проникність судинної стінки (протинабряковий ефект як на рівні головного мозку, так і на периферії); запобігає утворенню вільних радикалів і перекисному окисненню ліпідів клітинних мембран; нормалізує вивільнення, повторне поглинання і катаболізм нейромедіаторів (норепінефрину, дофаміну, ацетилхоліну) та їхню здатність поєднуватися з рецепторами; чинить антигіпоксичну дію, покращує обмін речовин в органах і тканинах, сприяє накопиченню у клітинах макроергів, підвищенню утилізації кисню і глюкози, нормалізації медіаторних процесів у центральній нервовій системі. Все це продемонстрував екстракт EGb 761 ${ }^{\circledR}$, який має складний, багатогранний, але вже доведений мультифакторний механізм дії, тому що за кожним цим ефектом стоїть доклінічне та клінічне дослідження, а за кожним пунктом в інструкції - доведена доказовість. Додатковим бонусом $\epsilon$ те, що препарат впливає на реологічні властивості крові, знижує агрегацію тромбоцитів і при цьому профілактує тромбоутворення. Все це дає можливість розуміти, за рахунок чого препарат проявляє нейропротекцію, за рахунок чого поліпшується слух, зменшуються вестибулярні розлади, чому припиняється прогресування нейродегенеративних захворювань при тривалому регулярному застосуванні у високих дозах - 240 мг/ добу, адже на сьогодні доведено дозозалежний ефект. Для лікування деменції та хвороби Альцгеймера рекомендована доза оригінального EGb $761^{\circledR}$ становить 240 мг/добу, що підтверждено результатами численних метааналізів з Японії, Китаю, Канади, США, Європи. Найближчим часом ще належить відкрити сторінку в лікуванні постковідних когнітивних розладів, і в наших руках вже $\epsilon$ надійна зброя, яку ми можемо використовувати для таких пацієнтів, адже науковий фармакологічний «background» для цього препарату вже закладено.

\section{Відомості про автора:}

Зайченко Ганна Володимирівна — доктор медичних наук, професор, завідувач кафедри фармакології Національного медичного університету імені 0.0. Богомольця, відмінник освіти України, член Міжнародного союзу фундаментальної та клінічної фармакології «UPPAR», Європейської асоціації клінічної фармакології та терапії «ЕАСРТ», Київ, Україна.

\section{Адреса для кореспонденції:}

Зайченко Ганна Володимирівна

03057, Київ, просп. Перемоги, 34
Information about the author:

Zaychenko Ganna V. — doctor of medical sciences, professor, Head of Department of Pharmacology of the Bogomolets National Medical University, Excellent Education of Ukraine, Member of the International Union of Fundamental and Clinical Pharmacology «IUPHAR», European Association of Clinical Pharmacology and Therapy «EACPT», Kyiv, Ukraine.

\section{Address for correspondence:}

Ganna Zaychenko

03057, Kyiv, Victory Ave, 34
1. Який компонент екстракту гінкго білоба асоційований 3 небажаними реакціями?

$\square$ терпенові лактони

$\square$ флавонові глікозиди

$\square$ гінкголієві кислоти

2. Який допустимий вміст гінкголієвих кислот зазначено у монографії із стандартизації екстракту гінкго білоба?
$\square<5 \mathrm{ppm}$
$\square \geq 50000 \mathrm{ppm}$
$\geq 5000 \mathrm{ppm}$

3. Яким чином EGb $761^{\circledR}$ впливає на нейротрансмітери?

$\square$ значуще підвищує рівень дофаміну

$\square$ майже не впливає на рівень серотоніну

$\square$ все вищезазначене

4. Рекомендована доза EGb $761^{\oplus}$ (Тебокан) у лікуванні деменції становить:

$\square 80 \mathrm{мг/добу}$

120 мг/добу

240 мг/добу

\author{
Для отримання сертифіката дайте відповідь \\ на тестові запитання в режимі on-line \\ на сайті журналу \\ www.umj.com.ua \\ або надішліть ксерокопію сторінок \\ з відповідями разом з контактною \\ інформацією за адресою: \\ 01001, Київ-1, a/c «В»-82, ТОВ «МОРІOH»
}

ПІБ

Поштова адреса: індекс
область
район
місто
вулиця
будинок
квартира
Телефон
E-mail

